\title{
Miranda
}

Revue pluridisciplinaire du monde anglophone /

Multidisciplinary peer-reviewed journal on the English-

speaking world

15 | 2017

Lolita at 60 / Staging American Bodies

\section{Two Bodies of American Photographic Work from the 1960 s and 1970s}

Joel Meyerowitz: Early Works, Rencontres d'Arles, 3 July-27 August, 2017 / Annie Leibovitz: The Early Years, 1970-1983, Rencontres d'Arles, 27 May-24 September 2017

\section{Daniel Huber}

\section{(2) OpenEdition}

\section{Journals}

\section{Electronic version}

URL: http://journals.openedition.org/miranda/10932

DOI: $10.4000 /$ miranda.10932

ISSN: 2108-6559

Publisher

Université Toulouse - Jean Jaurès

\section{Electronic reference}

Daniel Huber, "Two Bodies of American Photographic Work from the 1960s and 1970s", Miranda

[Online], 15 | 2017, Online since 04 October 2017, connection on 16 February 2021. URL: http:// journals.openedition.org/miranda/10932 ; DOI: https://doi.org/10.4000/miranda.10932

This text was automatically generated on 16 February 2021.

\section{(c) (i) $(9)$}

Miranda is licensed under a Creative Commons Attribution-NonCommercial-NoDerivatives 4.0 International License. 


\section{Two Bodies of American Photographic Work from the 1960s and 1970s}

Joel Meyerowitz: Early Works, Rencontres d'Arles, 3 July-27 August, 2017 / Annie Leibovitz: The Early Years, 1970-1983, Rencontres d'Arles, 27

May-24 September 2017

\section{Daniel Huber}

1 The $48^{\text {th }}$ (2017) edition of Les Rencontres de photographie $d^{\prime}$ Arles ${ }^{1}$ offered, amongst its varied and rich programme of some 40 exhibitions, retrospectives of two influential American photographers: Joel Meyerowitz: Early Works as the monographic highlight of the main programme of the Rencontres, and Annie Leibovitz: The Early Years, 1970-1983 as an associated programme commissioned and organized by the private LUMA Foundation. It is probably fair to say that the two artists are very different in their artistic ambition, in their motivation for showing their early work today and their choice of subject matter: therefore, their art will be treated on their own terms in separate sections, without much explicit comparison between the cuvres. Nevertheless, there is a coherence to treating them together here: both exhibitions presented a selection of work from the early career of the artists; more importantly, their early careers overlapped during the tumultuous history of the United States in the 1970s; and both cite Henri Cartier-Bresson and Robert Frank as major influences on their work and thinking about photography. Finally, they both fall within the limits of the period Mora (2007) calls "the age of the last photographic heroes", that is the years between 1958 and 1981, representing the arrival and critical acceptance of colour in art photography in the case of Meyerowitz, and, in the case of Leibovitz, building precisely on the personal documentary style of some of these last photographic heroes to apply it to the cultural and political affairs of the 1970s to create the iconic images that were published in Rolling Stone magazine and that would come to define the visual legacy of the period. Therefore, it is relevant to give an overview of their work as presented in 
Arles, showing how they started off on different tracks and how they reacted to a partially shared world, that of 1970 s America.

2 The two decades these two exhibitions cover between them are of crucial importance for photography, both in the history of American photography in particular and in the general history of the medium. This importance needs some discussion here. Luc Sante (2017, no page numbers) in his essay in the catalogue that accompanies the Leibovitz exhibition points out that in the early 1970s photography as a medium occupied an ambiguous position in the culture. It was still not seen as an artistic medium in its own right: the majority of museums stored their photographs as part of their print collection. Also, newspapers of the time that positioned themselves as more "literate and respectable" were text-intensive and did not accord much importance and space to photographs beyond inexpensive illustrative material, precisely in order to distinguish themselves from image-intensive tabloids and Harper's Bazaar or Life that were promoters of fashion photography and photojournalism, respectively. Mora (2007) identifies this period as that of the "last photographic heroes", that is of the American photographers of the 1960s and 1970s. He defends the position (Mora 2007: 9-11) that the period between Robert Frank's The Americans (1958) and the emergence of the postmodernist use of photography by Cindy Sherman in the early 1980s was a period where photographers - and the people that help them emerge, including curators, art critics and art directors, editors, gallery owners and art collectors - were seeking an independent photographic language because they believed in the unlimited capacity of their medium, and which they did push to its limits precisely in this period. This quest for freeing the photographic language of any pictorial contamination accelerated, through various experimentations with the medium, in the 1960s, and photography ultimately reached its independence by 1975 (as far as the United States is concerned, and later elsewhere). Sante (2017) also remarks that this coming of age was also reflected in the fact that some photographers had reached pop-cultural fame at this time. Mora (2007: 10) wrote, ten years ago, that it was only then that art historians had begun to take full measure of how this period impacted our contemporary use and perception of the photographic image because it was only in the middle of first decade of the $21^{\text {st }}$ century that we had the necessary distance from the period.

3 Mora's position is proved right by current curatorial practice. The Bibliothèque nationale de France hosted the exhibition $70^{\prime}$ Le choc de la photographie américaine [70s, The Shock of American Photography] between October 2008 and January $2009^{2}$, curated by Anne Biroleau. The Rencontres d'Arles, now showcasing Meyerowitz, presented photography by Stephen Shore in 2015 and Garry Winogrand in 2016 (in echo with contemporary photographer Ethan Levitas), while Winogrand also received a major retrospective at the Jeu de Paume in Paris in 2015, Aaron Siskind was presented in Montpellier in $2015^{3}$, Tod Papageorge at the Galerie du Château d'Eau in Toulouse in 2016. They are all major figures of the decades discussed by Mora. This period saw photographers grappling with the heritage left behind by Walker Evans (also presented in 2015 in Arles ${ }^{4}$ and at the Centre Georges Pompidou in Paris in 2017). Evans's lasting legacy was in particular his notion of the "photographic document", and contemporary reactions to it gave way to fertile discussions, and more importantly, exhibitions and book publications, around objectivity, subjectivity, neutrality and realistic illusion, which thus nourished a period of tensions and artistic creativity in the particularly rich cultural, economical and political context of the United States in the 1970s. 
In Mora's view, after this period, the photographic exploration of the real gave way to the exploration of the real as photographed, that is, of the image itself. Annie Leibovitz fits in precisely at the end of this period in the sense that her early work, very frequently on assignment for Rolling Stone magazine at this period, reacted in a consciously personal way to the economical, cultural and political climate of the 1970s and she produced work that ultimately created the defining and definitive images of those events. Her work, going far beyond a function of illustrative material in a magazine, is a powerful tribute and documentation of the intellectual and musical, but also political, scene of the troubled decade that was the 1970s in the United States. Her early work can be appreciated, in Humery's words, as her "formative experiences of the counterculture of the 1970s, the ecstasy of youthful abandon, and the urgency of personal and political upheaval". Leibovitz has contributed to freeing the photographic image from its illustrative function in magazine work so it can occupy a place of its own, being the narrative itself. When Cindy Sherman in an interview about her photographs with Vicky Goldberg of the New York Times in October 1983 (cited by Mora 2007: 171) declared she was an artist, not a photographer, what she meant is that for her, photography had become a readily available instrument for other artistic purposes rather than a tool for producing art as the aim of the exercise. This was only possible after establishing photography as an artistic medium on its own terms, and both Meyerowitz and Leibovitz contributed to this development.

5 As far as the aesthetics of this period of American photography is concerned, Mora (2007: 167-171) dedicated a whole chapter to the debate around colour photography at the end of the 1970s and, more specifically, how colour in art photography eventually imposed itself. While Mora concentrated on this period from the perspective of art photography, one should not forget that colour photography was not invented in the late 1970s. After various attempts and inventions, Kodachrome had been on the market since 1936 for colour slides and was used by some photographers of the Farm Security Administration between 1940-1941 (Mora 2007: 190, fn. 102). That said, early colour work of influential photographers has only recently been accorded due attention, a case in point being Capa's colour photographs that were shown at the Jeu de Paume in Tours in 2016 (and elsewhere on a world tour). By the 1970s colour had of course long been used in advertising and fashion photography ${ }^{5}$, and, for precisely this reason it was considered as the realm of the kitsch and popular culture (Westerbeck 2001: 13).

Most significantly for the history of art photography, Walker Evans had experimented in 1972-1973 with (colour) Polaroids using the mythical SX 70 camera, commercialized in its original run between 1972 and 1977 (he was actually offered the camera and an unlimited supply of film by the Polaroid company). Mora (2007: 54-55, 56-57), not quite accidentally it seems, included two photographs by Garry Winogrand, in colour, taken in New York in around 1961, a good decade before Walker's Polaroids, in a period where artistic expression was not yet considered acceptable in colour. Walker himself had, however, published photo-essays in colour as early as 1945 for magazines. The landmark Color Photography exhibition was on view at the MoMA in 1950 and another in 1951 entitled Abstraction in Photography. It was John Szarkowski, Director of the Department of Photography at the MoMA, who ultimately organized the first monographic exhibition of colour photography in May 1976, of William Eggleston's works, a young photographer from Mississippi in the American South who was virtually unknown to the public at the time (although he was friends with his contemporaries, 
including Meyerowitz). The question for prestigious museums such as the MoMA whether or not to collect and exhibit colour photography had become acute by the late 1970s and it revolved around the dilemma: is colour in photography valuable merely because of the technical prowess or is it because it is an emerging artistic language? Until 1970 colour photographs could not be safely conserved without the dyes turning with time, so museums were, legitimately, worried about the stability of their colour photography collections. Indeed, even Evans himself was divided about colour in photography when he wrote in 1969 (cited in Campany 2014: 60, and fn. 176): "It is a consoling thought that in about fifty years both color transparencies and paper prints in color - all the color photography done in this period - will very probably have faded away." This changed when Kodak introduced the dye-transfer process in 1970, which resulted in prints of much greater colour stability: this was the technique Eggleston used for his prints. The 1976 MoMA exhibition acted as a "catalyst", in Mora's formulation (2007: 169), and it freed photographers, as well as the institutions and the general public, of their mistrust with respect to colour in art photography. The visual history and iconography of the American still image has thus finally caught up with the film industry, which had long adopted colour.

\section{Joel Meyerowitz: Early Works}

7 The exhibition Joel Meyerowitz: Early Works was presented at the Salle Henri-Comte (3 July-27 August, 2017), as one of the exhibitions on the theme "The Experience of Territory" and it was one of the highlights of this edition of the Rencontres, the third under the direction of Sam Stourdzé. ${ }^{6}$ One of Meyerowitz's photos, "Sarah, Provincetown, Massachusetts, 1981" (chromogenic print of 1983) was chosen by Le Point and POLKA magazine for their special edition cover (freely available at the exhibition venues). ${ }^{7}$ According to Sam Stourdzé's curatorial intention (pasted on the wall in the exhibition space), the show continued the sequence on street photography the Rencontres had begun last year (he did not make it clear in his statement but he likely had Garry Winogrand/Ethan Levitas of last year in mind). However, another line of associations, that of presenting retrospectives of major figures of the decisive periods of American photography, can also be clearly discerned by regular visitors to Arles: the Meyerowitz show of this year thus follows on from the Walker Evans and Stephen Shore exhibitions in $2015^{8}$, the latter being another major American colourist whose work and influence also began in the 1970s, as well as the Sid Grossman exhibition in 2016 besides the Garry Winogrand exhibition just mentioned. One can hardly wait for the revelation of the programme for next year already!

8 Joel Meyerowitz, born in 1938 in New York City, has not had an exhibition at the Rencontres for 40 years, since the summer of 1977 (Petitbon 2017a: 149), and just like back then, the photographer came to Arles to present his work. ${ }^{9}$ There were 59 photos on view ${ }^{10}$, with one of them, "Longnook Beach 1977", being enlarged to a wallpaper ${ }^{11}$ on the back wall of the exhibition space. They were all, and this was unique, original gelatin silver prints from the 1960s and 1970s, never previously shown in France, from the artist's private collection and from the Howard Greenberg Gallery. ${ }^{12}$ Some of them must have been projected as a slide show in the 1977 exhibition, when Arles, among the first photography venues to recognize the importance of colour photography at the time (only one year after the MoMA show of 1976), chose to present Meyerowitz's work 
along with those by William Eggleston, Stephen Shore, Frank Horvat, and William Christenberry.

9 Sam Stourdzé, interviewed by Sarah Petitbon (2017a: 149$)^{13}$ for Polka magazine, reveals a number of unique features of the show. First of all, since printing in colour was very expensive at the time, "it is a privilege and a rarity to be able to present his original prints". According to him, one of the hallmarks of Meyerowitz's photographs is his extraordinary ability "to move from the bustle of the city to compositions that sometimes are close to still lifes", and the hanging of the material was indeed consistent with this curatorial position. Finally, the selection was meant to illustrate "the resolutely cinematographic dimension of his clichés, in their subject as well as in their colours, very Technicolor", which underlines his conspicuous "influence on a certain number of film-makers, such as Wim Wenders". This acknowledges the huge impact his work has had on establishing colour photography as a legitimate and respectable means of artistic expression. Street photography as subject matter and colour photography as aesthetics were thus the major curatorial messages of the Meyerowitz exhibition. But the exhibition was in fact even richer and broader in scope: there was a generous selection of 27 images in black and white out of the 59 prints on view, that is nearly half of the material, as well as a selection of 11 portraits taken with a large format camera at Cape Cod, Massachusetts.

The curatorial statement, presented in French and English, described Meyerowitz as a photographer who brilliantly captured the urban energy and excitement around him. In the black and white photography of his early career, his interest in the city and its motion is evident, he becomes part of the urban bustle. His gaze is alert, his complex compositions (playing against balance and frame) seem to be hanging by a thread, he excels in capturing unexpected details, whose chance and accident (literally and figuratively) then become testimony to the creative vitality and poetics of the city. During the 1960s, he moves towards colour which he invested with nobility and so raised himself into the ranks of a master colourist beside William Eggleston and Stephen Shore. He shattered the colour palette, translating sensation into dazzling chromatic contrast. He also moved with ease between the frenzy of cities and more contemplative compositions and his work is intricately involved in the formation of the visual imaginary of the United States as we know it today.

11 Campany (2014: 132) considers Meyerowitz among the photographers of the 1970s who tried to grasp the "monstrous incongruity" of the American nation, its ideological contradictions and sombre rituals. In Campany's opinion even his most represented subject, leisure activities and free time, became the source of disturbing humour. This humorous aspect was evident in a number of images hung in Arles, as in "Nun and young boy" (Rochester, N.Y., 1965) or the row of people sitting and waiting apparently for nothing in a Catskills resort in "Kutshers" (Catskills, 1963). Humour and an acute sense of urban incongruity is never far away, as in "Polka Dot Wall, Wyoming, 1964", a glimpse of urban creativity where dots painted on a wall give the wall a playful twist, but, and this is the source of incongruity, a man wearing a cowboy hat walks past, looking back straight at the camera with a suspicious serious look on his face. ${ }^{14}$ Meyerowitz reacted to a country that was overconfident in itself and its power of seduction, and Campany (ibid.) draws a parallel between the work by Meyerowitz and that of Robert Frank, both searching for forms and motifs that expressed this uneasiness. The parallel with Frank is all the more appropriate because Meyerowitz 
received The Americans in late 1963 as a gift from his former employer, Harry Gordon (Westerbeck 2001: 6), and it was decisive in his turn to black and white photography for some time to come.

In his interview with Brigitte Hernandez (Le Point, special edition, 2017: 4-5) Meyerowitz talked openly about his early career, and specifically about three aspects that became decisive in his career and that also bear on the exhibition in Arles: how he left the world of advertising for photography, how he became friends, among others, with Garry Winogrand early on in 1962, and how he was impressed by seeing Henri Cartier-Bresson at work. Having come from the world of advertising as well as wanting to become a painter explain in great part why he naturally took colour in photography for granted from the outset. It was therefore self-evident for Westerbeck (2001: 17, 19, 20-21) to include, as the opening images for his volume on Meyerowitz, three early photographs taken in New York in 1962-1963, in colour (not shown in Arles): one stolen through a shop-window of a young woman doing the hair of her boyfriend, another of a newsagent framed by the small window of her booth, and the third a snapshot taken at a parade. What is striking in these shots is that colours are evidently not an accidental component of the images, they determine the overall ambiance and colour harmony of the scenes, and thus the emotional impact of the image. It is also significant that in his own commentary on these three images, Meyerowitz did not even evoke colour as an innovative or pertinent aspect of the shots: what mattered to him was how these images had helped him overcome his innate timidity. In the interview (Hernandez 2017), Meyerowitz recalled how his chance encounter with Winogrand at a street corner and then taking the underground for the Bronx together made him turn to black and white photography, represented also in the exhibition in Arles. In Westerbeck (2001: 22), he evoked a different factor that made him opt for black and white at the time: the ability to enlarge and study his own prints in detail which was not possible with colour slides. Such slides were, he remembered in the interview with Hernandez (2017), what shocked Eggleston, visiting New York in 1968, because they were...in colour! Talking about his early career as a street photographer, he pointed out (Hernandez 2017) the physicality and choreography of taking photographs when he talked about how he was astonished seeing Cartier-Bresson at work in Manhattan and how he came to understand his aesthetics by seeing him work: photography in this sense is about choreography, about moving about the subject, it is dance. ${ }^{15}$ Westerbeck (2001: 3) described a similar impact that seeing Robert Frank at work had on Meyerowitz. Meyerowitz eventually decided for colour photography as his aesthetic preference in 1972, when he also adopted the large format camera because it made a better descriptive precision possible (Mora 2007: 182).

The exhibition space, the single room of the Salle Henri-Comte, was used efficiently to divide the material in a number of sections, without the separations made explicit. It made for a streamlined presentation of the prints. The chronologically earliest set of 15 images were in black and white and dated from the period until 1971. They showed scenes of the experience of the daily life of ordinary post-war Americans, and these images fit squarely with Westerbeck's appreciation (2001: 10) in that they reflect the classic street photography aesthetic of capturing little everyday moments and thus they constitute a spiritual commentary on human behaviour. Some showed people at their workplace, such as in a fast food restaurant ("Atlanta, Georgia, 1971"), or in the humorous shot "Movie Theater Booth, Times Square, New York, 1963" (Figure 1) showing an employee sitting in her ticket office with the hygiaphone masking off her 
head (see Westerbeck 2001: 24-25). Others showed people at the visual absurdity of their various leisure activities: a family in public places such as at the airport patiently waiting, in the exhibition space of the space centre (in Cape Canaveral, Florida?), at a circus or cinema. Yet others took an instant shot of an encounter between visually/ iconographically incompatible people as in "Nun and young boy" (Rochester, N.Y., 1965) or scenes such the woman sitting alone, seemingly lost in her thoughts and looking down, in a space capsule. In connection with an image in Westerbeck (2001: 30-31), not shown in Arles, Meyerowitz remarks that one could put people together within the frame who do not know each other because it is the frame that creates the meaning: it is clear that what Meyerowitz is after is not documenting reality as such but a quest for a different level of meaning. Of course, some of these images might look trivial today, especially for Western viewers, but at the time of their taking they visualized aspects of the increasingly solidified consumer society in its less glamorous moments such as downtime spent waiting during more and more frequent travels by air. But it is precisely the fact that these scenes are still so familiar and that they are perceived without the visual shock of the time that is most disquieting to a contemporary viewer: what was seen as incongruous at the time has ceased to be surprising today. His particular fascination for leisure activities and the topic of free time was honoured with a Guggenheim Fellowship in 1970 that allowed him to travel across the United States photographing this subject (Westerbeck 2001: 126).

Figure 1

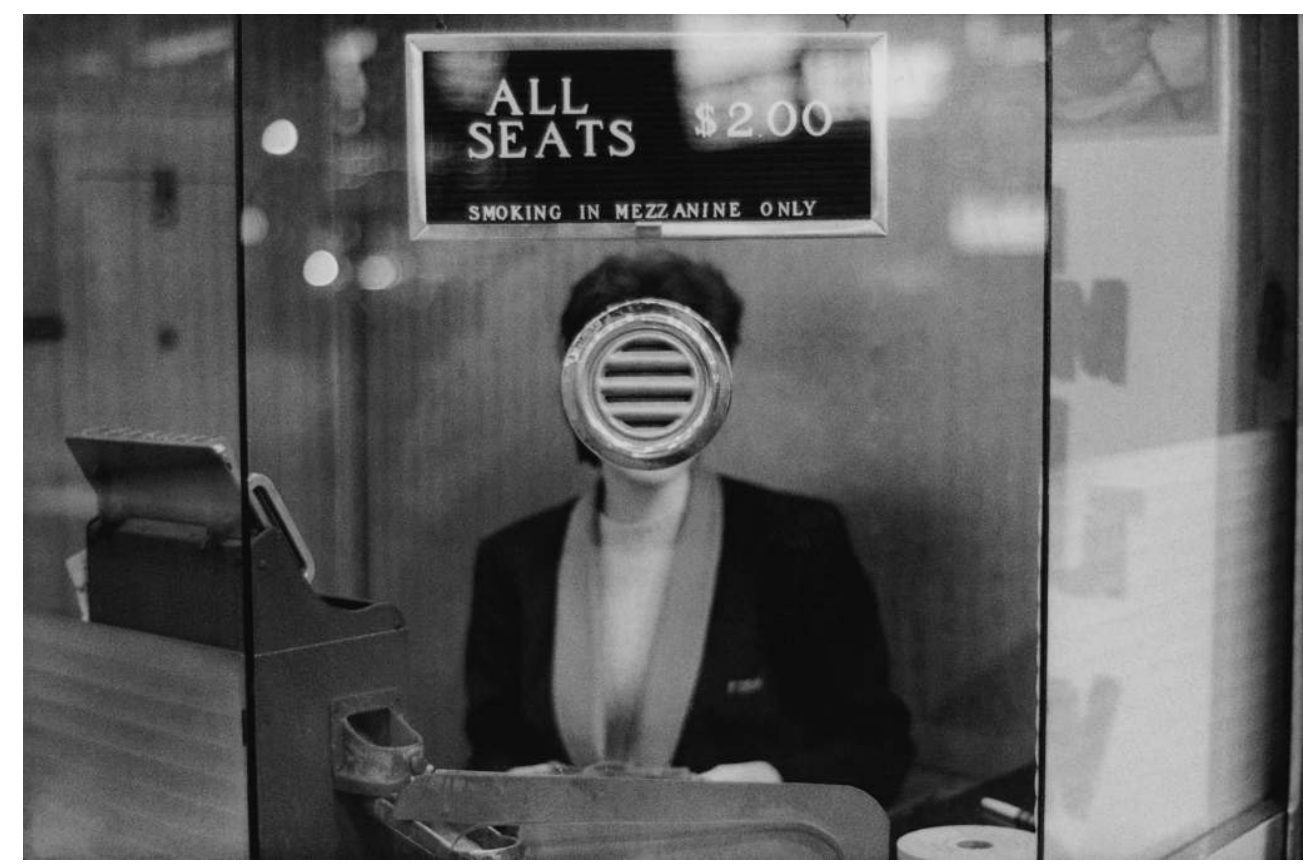

Joel Meyerowitz, Movie Theater Booth, Times Square, New York City, 1963.

Courtesy of the artist and Howard Greenberg Gallery. COPYRIGHT: Rencontres Arles

The next set were 13 images, 7 black and white, 6 in colour, taken in New York City and which represented the bustle of the city in all its aspects, all of them well-known iconic Meyerowitz shots. These images were arranged in a way that three large colour prints provided the separation between two groups, of four and six images, respectively. The three large prints are particularly significant because they illustrate the change in his 
aesthetic quest during this period: contrary to his earlier black and white photos, they are more encompassing images that translate the tension, complexity and density of city life, as analyses Westerbeck (2001: 10). This is his first original contribution to the street photography tradition because colour becomes the single element that justifies the taking of the picture in the first place. The opening large colour print in this section was the well-known street scene at the crossroads/corner of Broadway and 46th street (New York, 1976): this is a brilliant case of testing the aesthetic possibilities of a flat image in colour where all the informative elements, in the foreground as well as in the background, require equal attention, where there is no central subject, no perceptible depth of field, and where the colour palette plays an important role in making the image. This is a brilliant counterexample to the dictum of Cartier-Bresson's decisive moment because in this image there is, deliberately, no decisive moment (Westerbeck 2001: 96), only graphic quality. The second dividing picture was the equally well-known image "Camel Coat Couple in Street Stream" (New York City, 1975), which was, in his words (Westerbeck 2001: 94-95), a lucky coincidence with the play between the two pairs of camel-coloured coats and a pair of shadows cast on the right pair: the result is a masterly study in colour aesthetics in photography (Figure 2). This artistic stance illustrates well what Mora (2007: 10) described as the quest of photographers to push the photographic medium to its aesthetic limits. It was the closing image of this group that became a personal favourite: "Young Dancer" (New York, 1978), which derives from his series Empire State (1978-1980) that AT\&T commanded in 1978, specifically in large 20x25 cm format, and in colour (Westerbeck 2001: 127). What is appealing in this image is how colour and form were treated in it: the young female dancer in green dress is set against the red wall framing a shopwindow (of a fast food restaurant?) and her upright posture is parallel to the shape of the Empire State Building, visible at the end of the street in the background, and to the façade of the building across the street to the right. 
Figure 2

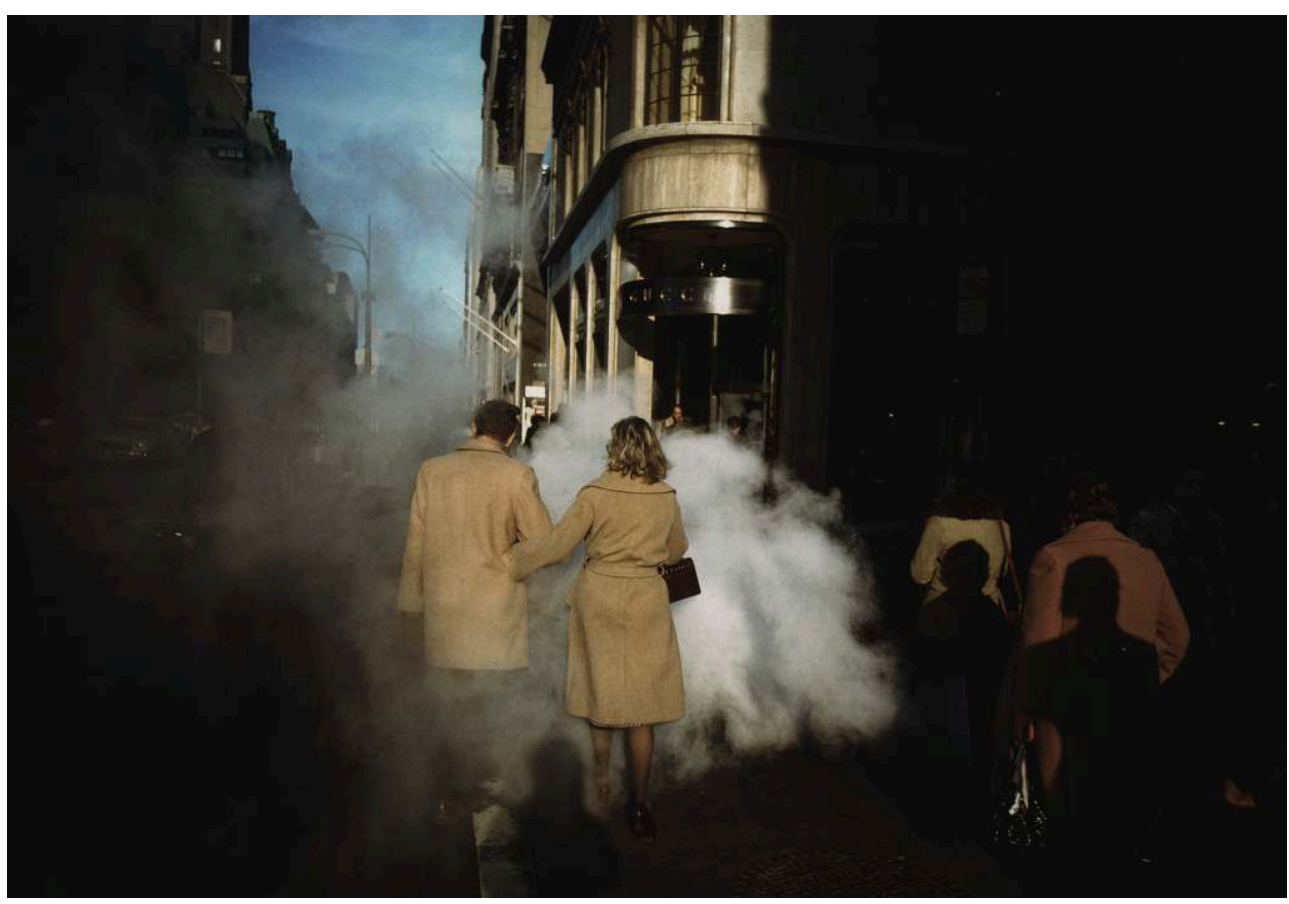

Joel Meyerowitz: Camel Coat Couple in Street Steam, New York City, 1975.

Courtesy of the artist and Howard Greenberg Gallery. COPYRIGHT : Rencontres Arles

The first of the two groups of images between the large colour prints just discussed, showed urban encounters such as ferocious dogs barking at another dog held on leash by a demonstrator against the Vietnam War (taken in 1968) or a person disguised in a gorilla costume walking down the street in 1965, all in black and white. The other group, of six black and white and colour images hung together, showed scenes from New York, pedestrians in the street, at the metro entry, a glimpse of his way of doing street photography in colour. They illustrated how colour can be used to express similar representations as in black and white. This set of images also included clear references to the car culture of the American society: Meyerowitz took photographs of people in cars decorated with the American flag for a national holiday, or the aspect of a car wash. Campany reports (2014: 132) that Meyerowitz recognized that in a certain regard, the car itself was a camera, its windscreen providing the frame for the scene happening outside. His first personal exhibition, at the MoMA in 1968, was called My European Trip: Photographs from a Moving Car, and it presented work during his trip to Europe, which is a telling counterpart to Frank's trip across the United States for The Americans ten years earlier (Westerbeck 2001: 8).

16 On the back wall of the exhibition space, with the wallpaper enlargement of "Longnook Beach" (1977), were hung 6 images in colour. To the left were three photographs of "Provincetown, Cape Cod 1976", vernacular architecture reminiscent of Walker Evans, big cars and fences, but that were in fact accessories of the beach culture of summer holidays rather than downtown vestiges of earlier architecture. To the right were shots of bungalows that show up strongly as foreshadowing the drama and tension of the colour treatment practised later by Todd Hito. This was the part of the exhibition that in appearance showed scenes without much human presence, but of course every thing, from the built environment to the cars, and the artificial lights, implies human 
presence - consumerist human presence in particular. The famous "Red Interior, Provincetown, 1977" was hung here: the large format image of a big car with its doors open and red light flowing from inside, setting the contrast with ambient green hues coming from the street-lights, reflected on the white walls of a row of bungalows (Mora 2007: 182-183). The apparent absence of human figures in these six images was efficiently counterbalanced by the wallpaper photograph that did show people at the beach, although, quite fittingly, faceless and impersonal because back to the camera.

On the right wall, at the angle next to the wallpaper wall, were hung 11 portraits, all in colour, and taken in the Cape Cod area (mainly in Provincetown, Ma., or nearby, for instance, at Ballston Beach near Truro, Ma.). They also helped to counterbalance the absence of human figures on the back wall. It is from this group of portraits that the image of "Sarah, 1981" is taken. All the portraits were in the context of the beach, either at the seaside or with a bungalow in the background. Perhaps even more importantly, these photos were taken with his newly acquired large format camera, a Deardorff 8x10in, that he used for the first time at Cape Cod during the summer of 1976: it was precisely the descriptive capacity of this camera that made him discover portrait photography. ${ }^{16}$ Next to this set of portraits was one huge image in colour, "Land" (Provincetown, 1976), that represented the fast food and car culture on the East Coast summer resort site, with considerable humour resulting from the two cars parked in a way that forms a wedge, pointing towards the sign "food" under the name of the restaurant, "Land". This restaurant also figured in another image in the last group of photographs, but that image had a different emphasis: it focused more on the typography of the neon sign and the aspect of the building, as shown in curious lighting conditions. This last group of images, 4 in black and white, 8 in colour (plus "Longnook Beach" in its original print hung a bit further away from the rest of the images), showed a miscellany of photographs from different periods of Meyerowitz's career. Some represented elements of the beach culture on both coasts and travel abroad (such as the famous shot in Greece from his travels in Europe between 1966-1967), while some focused more on the typography and graphic quality of hoardings and advertisements, and still others did not seem to have an apparent link within the set. This last section was the only part which could have used more coherence but that did not distract from the quality of the prints themselves.

The display of the material was fluid and coherent overall, maybe less so in the final panel, and was consistent with the curatorial intention of offering a representative selection of Meyerowitz's work and his interest in everyday scenes, the visual absurdity and humour of leisure activities at a resort or at the beach, chance encounter between people, and most importantly: his unique and innovative use of colour to aesthetically convey atmosphere and emotions, his own feelings first of all, but that resonate with the viewer. It was also efficient and aesthetically pleasing to have the back wall decorated with the wallpaper print of one of his pictures that balanced off the images hung on that wall. As is usual at the Rencontres, all captions and descriptions were bilingual in French and English. Unfortunately, however, there was no catalogue published to accompany the exhibition. A short dedicated catalogue would have been welcome since this specific selection has not been shown before and the curatorial procedure was consistent and convincing. For those who will have missed it in Arles, the exhibition will travel to the Jimei $x$ Arles international photo festival (Xiamen, China) 24 November 2017-3 January 2018. 


\section{Annie Leibovitz: The Early Years 1970-1983}

19 Foundation presented its first "Living Archive Program" show with the exhibition Annie Leibovitz, The Early Years, 1970-1983. Archive Project \#1 (27 May-24 September 2017) in the Grande Halle at the Parc des Ateliers. ${ }^{17}$ It was in 2013 that Maja Hoffmann launched "LUMA Arles", after creating LUMA Foundation in 2004 based in Switzerland, to plan, develop and manage the Parc des Ateliers. This site is a sixteen-acre (10-hectare) industrial area formerly occupied by SNCF railway workshops originally built in the middle of the $19^{\text {th }}$ century, just off the historic town centre of Arles, and where the traditional and original exhibition spaces of the Rencontres d'Arles used to be located. The "Living Archive Program", under the direction of Matthieu Humery, aims at integrating photography, design, literature, film, dance, and other media into a series of exhibitions and cultural programmes. ${ }^{18}$ As their first archive project, they acquired, last winter, the archives of Annie Leibovitz (about $8000^{19}$ negatives, original exhibition prints, contact sheets and contact prints, books and even her contemporary technical notes. ${ }^{20}$ ). The present exhibition is intended as the first of a series of projects dedicated to the study and reinterpretation of her living archives. If this ambitious exhibition is any indication, the LUMA Foundation is serious about its business in the domain of mounting contemporary photography exhibitions in Arles outside the Rencontres and now it has become clear that their ambition is that Arles is no longer associated exclusively with the Rencontres. It is in this perspective that the visit to the Rencontres of Françoise Nyssen, Minister of Culture and founder of the local publishing house Actes Sud, was of significance. ${ }^{21}$

Petitbon (2017b) provides valuable insight into the acquisition of Leibovitz's archives in its wider context of current trends of living photographers to find ways to the posterity and the long-term conservation of their work. Just like Elliot Erwitt (b. 1928) ${ }^{22}$, Leibovitz had been thinking about the future of her negative and print archive, as far as its conservation is concerned, but more importantly, as for its diffusion in the future. Michel Poivert (cited by Petitbon 2017b), who had gained his experience in the domain studying the archives of Gilles Caron, thinks that this kind of attention to their own archives is a sign that photography has reached maturity. There are of course other archive solutions such as in magazines or agencies, as in the case of the Condé Nast archive $^{23}$ (for Vogue magazine and others) or the Magnum archives, but these only conserve the material that had been produced for them by a photographer and do not encompass the whole cuvre of the artist. Some photographers, or their heirs, have chosen to establish a private foundation, such as the Fondation Henri Cartier-Bresson or the Helmut Newton Foundation; others leave their legacy to the state, like André Kertész or Willy Ronis, or for their descendants to manage, like Robert Doisneau; yet others have chosen to sell their archives.

Leibovitz, after selling her archives, chose to do the selection and reinterpretation herself, now knowing that her legacy is protected. It was likely an exceptional occasion for her to do this retrospective work since her dense career did not make it frequently possible for her to look back on her work, confessed Robert Pledge, her friend and patron of the Contact Press Images agency. It is nevertheless true that Leibovitz has published two volumes of retrospective material, one covering the years 1970-1990 
(mainly professional rather than personal photos) and the other, those spent with Susan Sontag between 1990-2005 (exclusively personal photos). The retrospective in Arles combined personal and professional material, although the two types were never mixed on the walls and the personal sections, present in all rooms, were consistently captioned while most of the professional material was not captioned.

The period the exhibition covers, 1970-1983, is not accidental: the archive material highlights her work from the period she spent at Rolling Stone magazine and when she was based in San Francisco, California (even though many of the images were not taken there and she was a regular to Andy Warhol's Factory in New York). This was a period of tremendous social, political and cultural changes in the history of the United States, of which California was at the centre and where politics and popular culture had merged, providing fertile ground for an unusually wide range of subjects and events to be covered. The 1970s was a period, in Sante's words (2017, no page number), where "[l]arge personalities...were now to be found not only in movies and music, but in sports, comedy, fashion, politics, literature, and even journalism". Covering the events in words was the duty of journalists writing for Rolling Stone such as Tom Wolfe and Hunter S Thomson, who established what would come to be known as New Journalism, grounded in exhaustive reporting. She took portraits and photographs of all the musicians, artists and writers, and politicians or political activists who came to prominence at the time: John Lennon and Yoko Ono, Paul and Linda McCartney, Louis Armstrong, Joan Baez, Patti Smith, Aretha Franklin, Carlos Santana, Mick Jagger, Leonard Cohen, Bob Dylan, Bruce Springsteen, Nina Simone, Bob Marley, Jack Nicholson, Dennis Hopper, Jane Fonda, Roman Polanski, Wim Wenders, Andy Warhol, Norman Mailer, Tennessee Williams, Truman Capote, Ken Kesey, Hugh Hefner, Arnold Schwarzenegger, Muhammad Ali, Henry Kissinger, Senator George McGovern, to cite a few..$^{24}$ This period was crucial in her life as a photographer: as she recalls in her introduction to the catalogue (2017, no page numbers), "[r]oad trips were at the heart of my work in the early years at Rolling Stone. It was a continuation of my childhood. Seeing things through a car window was something I had been doing all my life." One of the recurrent visual features of her images in virtually all the rooms of the exhibition was indeed the photographs that came to form her "Driving series", portraits of all manner of people taken in cars, and which form the cover of the catalogue.

The hanging of the material required a less conventional attitude from the visitor: it was not immediately self-evident how to try to take in around 3000 images, mentally, conceptually and emotionally. It was an unconventional, slightly unusual, and overwhelming, way of presenting this body of work, but it was in line with the curatorial intention of providing dynamic and innovative displays for the "Living Archive Program". The visitor was aided by the numerous text panels in each room, which summarized, in French and English, the main themes of the years displayed on the adjacent wall space. While the presentation did work for the present reviewer and very likely for countless others, it would be easy to understand that some visitors did not get to appreciate the individual image drowned in the wall of surrounding images (see Figure 3). In this respect, the presentation of the material did significantly differ from presenting photography at the Rencontres.

24 The title of the exhibition makes it clear, though, that the visitor is invited to appreciate an archive of the early career of an influential photographer. The arrangement was essentially a literal reference to "archive", displayed on walls rather 
than on shelves. The exhibition did resemble Leibovitz's actual studio that can be seen at various places in the film Annie Leibovitz. Life Through a Lens (2006/2009). Petitbon cites (2017b: 34) Matthieu Humery in confirmation of this first impression of the visitor: the exhibition space was indeed conceived as a close reproduction of her current New York studio, specifically. In terms of more general iconographic references, the arrangement of the material was reminiscent of collages. Quite pertinently, the opening image in the catalogue of the exhibition (2017, no page number) shows Leibovitz's black and white photograph, captioned "Hunter S. Thompson's kitchen, Woody Creek, Colorado", which had photographs, Polaroids, invitation cards, newspaper clippings and other documents pinned on a wooden panel revealing the juxtaposition of intimate, personal moments and past or future public appearances of the journalist. This photograph is very much in tune with the overall atmosphere of this archive material.

Figure 3

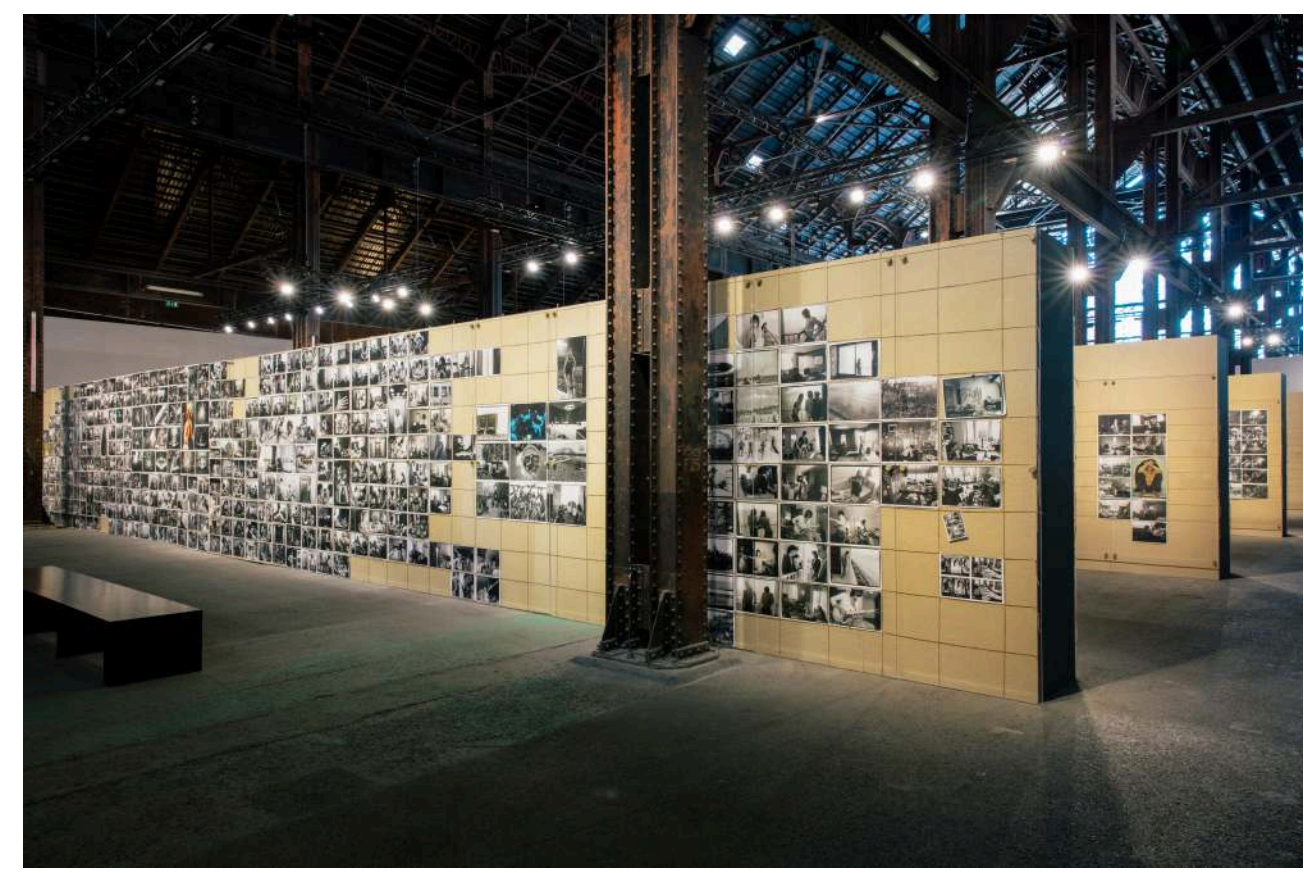

Installation view of "Annie Leibovitz The early years: 1970 - 1983. Archive Project \#1"

(c) photo Victor Picon

The explicit references to "archiving" was also evident in the particular display of the material: the walls had smaller or larger groupings of photos that appeared to follow a thematic organisation, in approximate chronological order, without the themes explicitly labelled. Sometimes a group of prints was placed on top of each other and all pinned onto another image or to the cork wall panel, as if they were a group of images still waiting to be sorted out, or rather, for only one of them to be selected. As a consequence, some images were placed so high one could not actually get to see and appreciate them, as in the case of the prints of Nina Simone. A selection of images was supplied with a red drawing pin with a number on it, like objects at an excavation site: the number referred to the caption (typically the name of the person), which were all gathered together somewhere else on the wall. Unfortunately for the visitor with less than general cultural knowledge of the period and the personalities that inhabited it, it 
was much more difficult to find a particular pin (and the image it marked) corresponding to a caption: some pins were placed so high that it could hardly be made out or simply they could not be found because the pins did not appear to follow any numerical or chronological order on the wall - either you could recognize Carlos Santana, Alice Cooper or Tina Turner in the early 1970s or you could be hard pressed to find them. However, it was an original idea of organizing the material that the cork panelled walls hosting the images were also supplied with fibre cords as if at an archaeological site, dividing the wall surface into smaller parcels (see Figure 4). Furthermore, all the panels were under protective Plexiglas that was a couple of centimetres removed from the surface of the images, reminiscent of protection for some exquisite piece of Gallo-Roman mosaic wall: this technique did help the images breathe under protection and contributed to the archaeological presentation of the material. Humery in his Foreword to the catalogue (2017, no page number) does indeed talk about this purposeful return to her early work "as an archaeology of the self, where the passage of time enables a productive re-reading of ego and epoch alike".

Figure 4

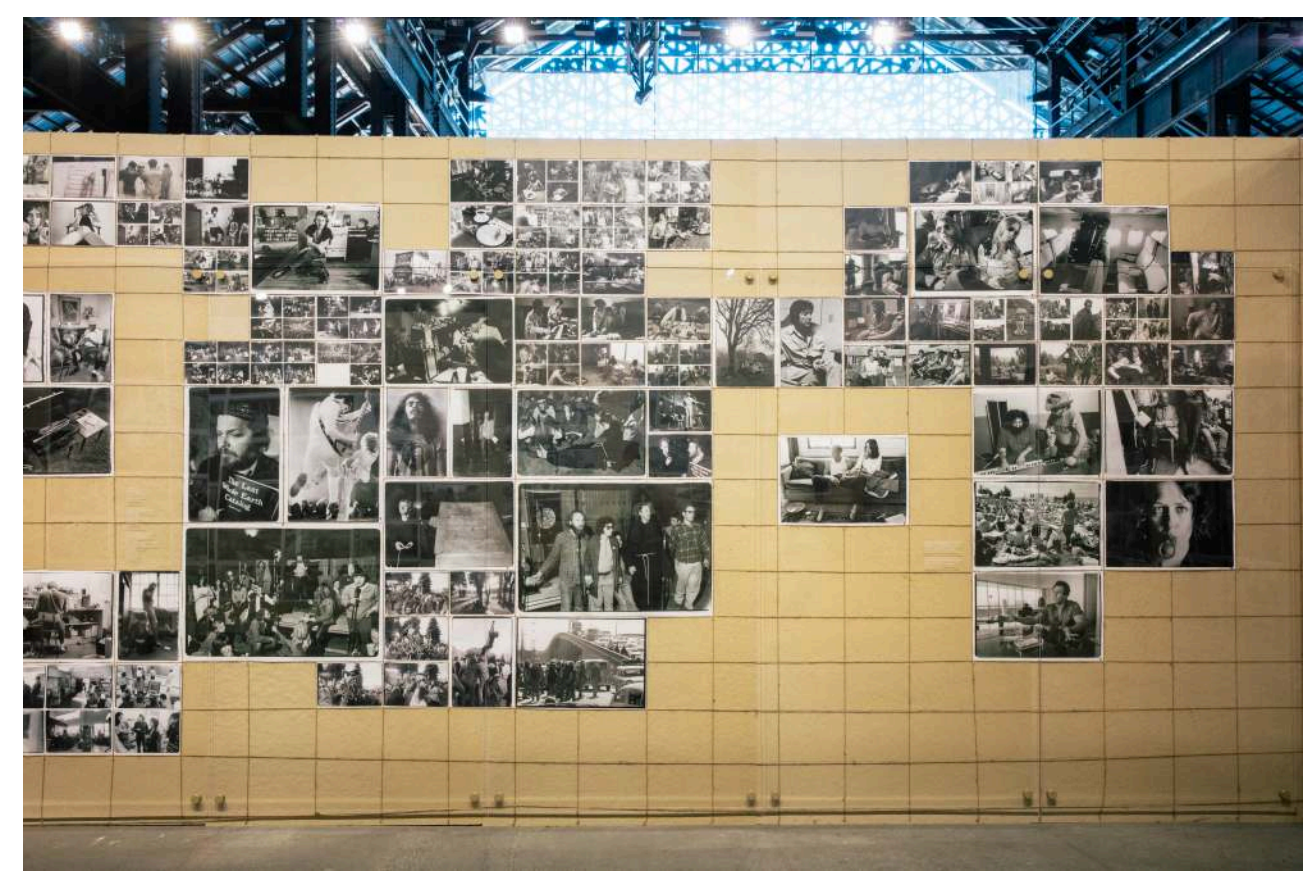

Installation view of "Annie Leibovitz The early years: 1970 - 1983. Archive Project \#1"

(C) photo Victor Picon

A further association with the archaeological aspect of the exhibition is precisely the absence of labels naming the themes or topics and captions to the individual image, as if calling on the viewer: "Do you recognize these people?", "Do you know what these events meant at the time (and now)"? Sometimes it is a well-known particular event such as Nixon's resignation on 9 August 1974 or the 1975 American tour of The Rolling Stones; sometimes scenes from the protests of the late 1960s and the 1970s where emphasis is more on the atmosphere than on the particular day of protest; sometimes it is shots at interviews or backstage. What stands out today as a landmark moment in politics, in the cultural scene or the musical arts in particular was an episode in the flow of the days of a photographer at the time: this explains why, at the time of their 
taking, they all had their specific importance, their significance can only be appreciated in hindsight. This might be a good conceptual reason for not indicating the themes in the display because at the time they had not yet become a topic: the identification of the topics is the work of the posterity, the exhibition shows the archaeological site at a preliminary stage of excavation. (This is also a call on researchers to delve deeper into this wealth of archive material.) Indeed, this general absence of captions together with the presence of the occasional drawing pin was the reflection of the archiving and selection process. In conclusion, many elements of the Leibovitz show consistently played with references to archaeology and the method of archiving.

The display was chronologically arranged in eight rooms after an entry room with biographical and historical material to better contextualize her artistic output. The chronological organization was first of all visitor-friendly, but it is also consistent with her earlier practice of presenting her work, as in the book A Photographer's Life: 1990-2005 (Leibovitz 2006). The first room of images, "1970-1971", presented her photographs from the time when she became a painting major at the San Francisco Art Institute, the influential art school where she had enrolled in September 1967. There are two important aspects of her career that need to be discussed in connection with the material presented in this first room: her enrolment at the San Francisco Art Institute and her involvement with Rolling Stone magazine.

Leibovitz, born in 1949 in Waterbury, Connecticut, bought her first camera in Japan in the summer of 1968 when on visit to her father's airbase in the Philippines. She took a night class in photography the next semester and an intensive workshop the following summer at the Art Institute and then changed her major from painting to photography and moved over to the legendary Photography Department of San Francisco Art Institute. Here, Henri Cartier-Bresson and Robert Frank were the heroes of contemporary photographic practice and the aesthetic and stylistic aim was to produce personal reportage shot with a handheld, $35 \mathrm{~mm}$ roll film camera in black and white. This was a transformative experience because here, as Sante in his essay in the catalogue summarizes (2017, no page number), Cartier-Bresson gave students a purpose, Frank an aesthetic. While Cartier-Bresson "roamed the world as a photojournalist, shooting uncannily composed, nearly sculptural pictures amid scenes of chaos", Frank "conveyed the troubled atmosphere of the [American] nation in subjective, emotional pictures that employed glare, grain, and off-kilter framing" in The Americans (1958). Students were taught to compose in the camera rather than aiming at later cropping, and they were taught to develop film and make the prints on their own. As a result of this accelerated training, Leibovitz had already mastered discipline when she approached Robert Kingsbury of Rolling Stone with her images of the anti-war demonstrations in San Francisco.

Sante (2017, no page number) recalls the early history and importance of Rolling Stone magazine. It was established in 1967 in San Francisco, with Jann Wenner as editor, Robert Kingsbury as art director and Baron Wolman as chief photographer (until late 1970). Their first issue came out on 9 November 1967 and soon it became more and more established as the voice of the youth culture after the Summer of Love of 1967, and one of the rare major magazines not to emerge from New York City. It combined the aura of San Francisco as the dream of teenage runaways with a seriousness unmatched in other contemporary music papers: this combination helped it establish 
itself as a news magazine for the counterculture. Sante notes that at this early period of the magazine, "the use of photographs was often little more than utilitarian, cramming together small pictures at the top of the page that illustrated multiple stories in the columns below". This observation is much in line with what Mora (2007) said was the general attitude towards photographs at the period. In the 14 May 1970 issue, Leibovitz had her first image published in Rolling Stone magazine, in its "Dope Pages": a shot featuring Allen Ginsberg. On 11 June 1970 she had garnered her first cover together with further, unrelated images inside, including another shot of Ginsberg. Other assignments followed soon, while she was still a student. The centrepiece of each issue was the "Rolling Stone interview", which had, however, lacked a sense of intimacy and a physical presence because it could not be conveyed by the merely illustrative images at the time. This changed when Leibovitz shot her session with Grace Slick of Jefferson Airplane, interviewed by Ben Fong-Torres, for her first cover feature of the November 1970 issue. By December 1970 she went to New York to photograph John Lennon (and Yoko Ono) interviewed by Wenner, her career-making assignment: her name was printed on the masthead of the magazine under "Photography" and in 1973 she became chief photographer for the magazine. Altogether, Leibovitz would produce 142 covers for Rolling Stone in the thirteen years she spent with them. A selection of these earliest covers and features was displayed in a thematic unit in the first room, together with the early images and her shots at Kibbutz Amir in Israel in the autumn of 1969.

The second and third rooms, "1971-1972" and "1972-1973", showed her early stories for Rolling Stone, for instance on the Soledad Prison on the occasion of the return home of the political activist David Harris (who had refused to be inducted into the armed forces during the Vietnam War), the night launch of Apollo 17 on 7 December 1972 with Tom Wolfe reporting and half a million people watching, or her documentation of the tour of the Allman Brothers. When she covered the 1972 presidential campaign (where Nixon ran for a second term and won), with Hunter S Thompson reporting, she was among the very few women journalists to cover the events. Rolling Stone covering the presidential campaign (with an explicit endorsement for the Democrat candidate McGovern) and the music scene especially in San Francisco was the natural expression of how contemporary protest music (Joan Baez, Pete Seeger, Grace Slick and the Jefferson Airplane, The Grateful Dead, among others) fuelled the cultural revolution which was as much about politics as about lifestyle and music. She also covered other music festivals such as the country music festival Dripping Springs Reunion in Texas in the spring of 1972 that eventually contributed to establishing Austin, Texas, as an alternative centre of progressive country music besides Nashville. The 1970s, which Wolfe would later label the "Me Decade", was the decade of the proliferation of spiritual guides and gurus for tens of thousands in a quest to develop their human potential. One of her first colour photographs on view is a scene with people sitting or lying in a random scattering on the ground of what looks like a giant flat open-air public space with a desert-like background, apparently well ahead of time, waiting for Guru Maharaj Ji of the Divine Light Mission. 


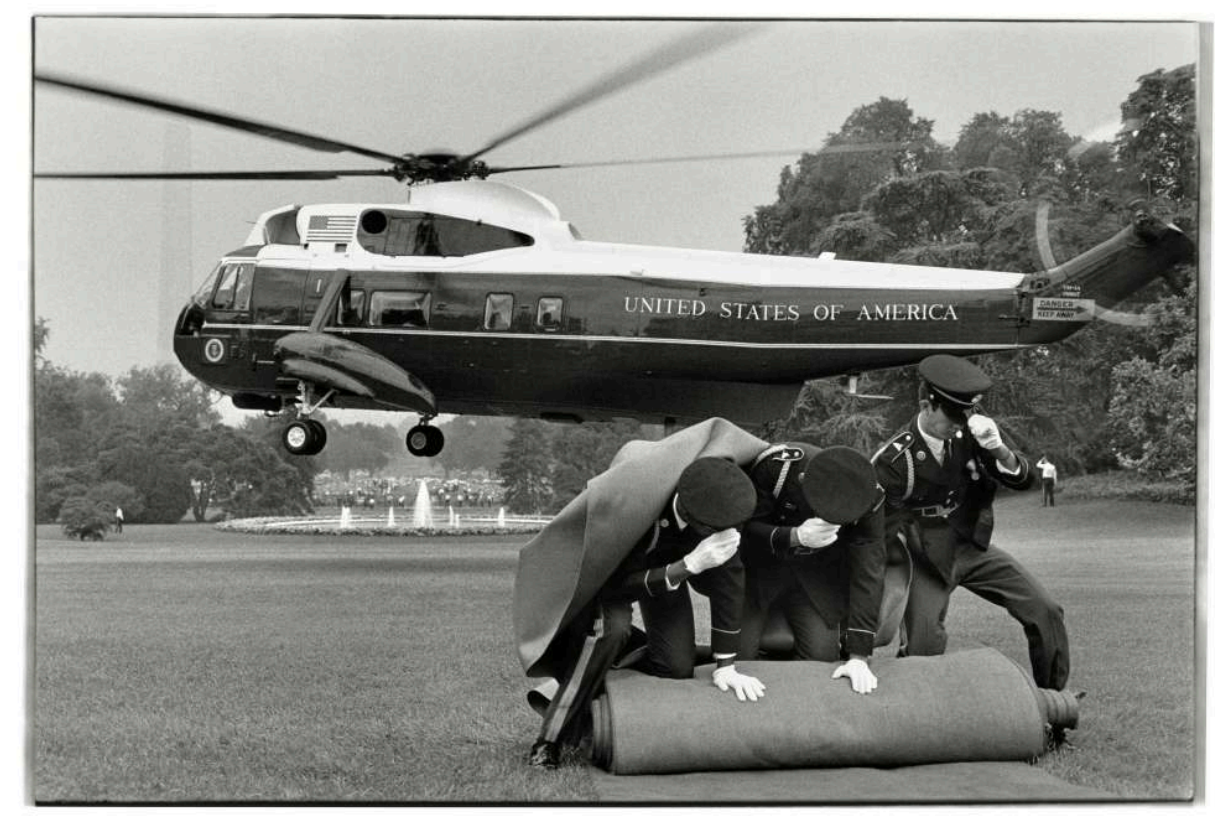

President Richard Nixon's resignation, Washington, D.C., August 8, 1974

(c) Annie Leibovitz. From Annie Leibovitz The early years: 1970 - 1983. Archive Project \#1

31 The dominant theme in the room dedicated to "1974" was Nixon's resignation. It is, of course, a subject in its own right. Leibovitz and Thompson were sent to cover the events of 9 August 1974 but Thompson did not turn in his report before the September issue went to press, so it was her photographs in their own force that appeared in the 12 September 1974 issue of Rolling Stone, to cover Nixon's resignation, with her name on the cover. Her photo-report included the two probably most iconic images of Nixon's resignation in the collective imagination: Nixon's face captured on a TV screen while he announced his decision, and the image Leibovitz took when his helicopter had taken off and officers were rolling up the carpet fighting the wind from the propellers (Figure 5). This room also featured some early colour photographs, the portrait of Norman Mailer, Roman Polanski and Tennessee Williams, as well as black and white portraits or photographs of other artists and musicians such as Elton John and Jerry Garcia.

The wall section leading over the rooms 5 to 8 was entirely devoted to the two-month long Tour of Americas of the Rolling Stones in 1975 that Leibovitz covered in literally every aspect, shot on "hundreds of rolls of film" as the text on the wall in the exhibition space revealed. There were 417 images on view ${ }^{25}$, and they possibly form "the summa of her photojournalism" according to Sante (2017) where she has "ridden participatory journalism to its edge". She bore witness, in an excellent series of photoreportage photographs, to the extremes of such an adventure: from stage shots to backstage scenes as well as images of the idle time between and before concerts or that of fans waiting for their stars (Figure 6). It really is a mix of images bursting with energy on stage, funny moments backstage and off stage, but also moments of isolation and reclusion to a solitary, somewhat melancholic state of mind such as on the image 
showing Mick Jagger sitting alone at the foot of his bed on the floor in his hotel room watching some sports programme. She wrote: "A rock and roll tour is unnatural. You're moving through time and space too fast. The experience is extreme. There is the bigness of the performances and then the isolation and loneliness that follow. The band was like a group of lost boys, but their music saved them."

Figure 6

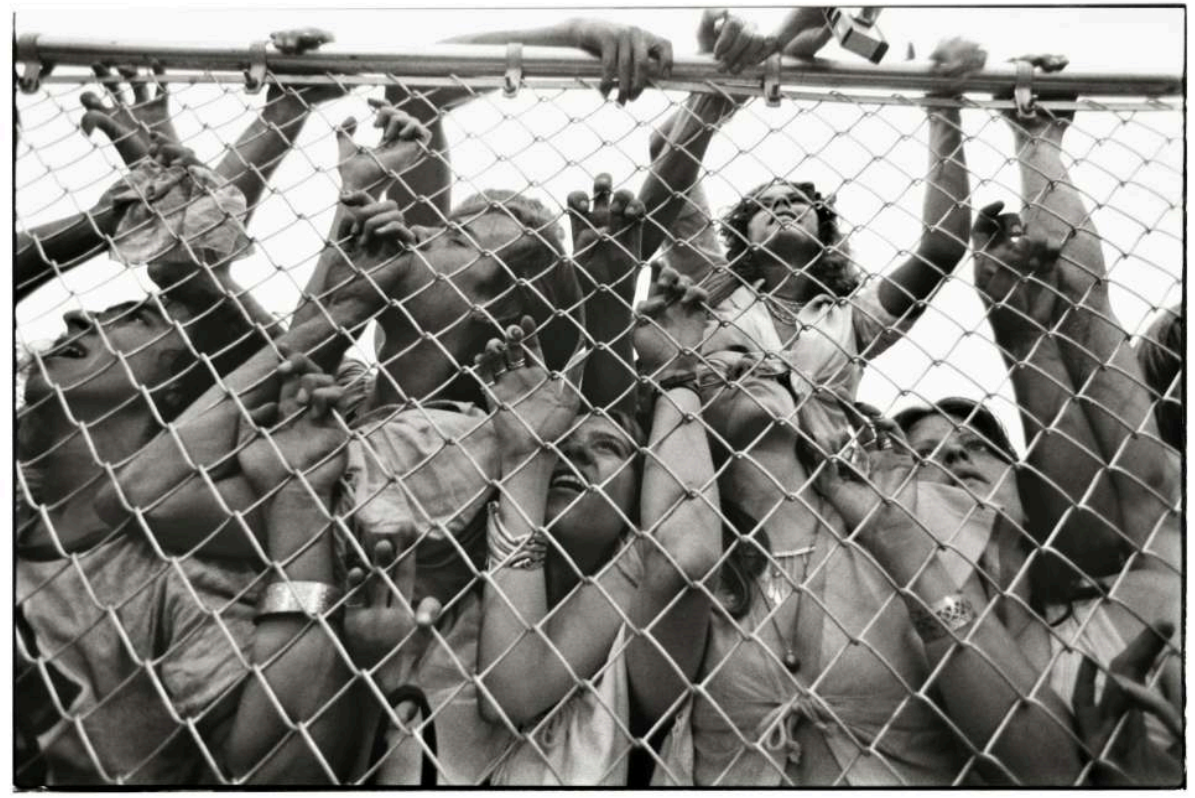

Rolling Stones fans, Cleveland, Ohio, 1975

(c) Annie Leibovitz. From Annie Leibovitz The early years: 1970 - 1983. Archive Project \#1

Rooms 5 to 8 covered periods after the 1975 tour of the Rolling Stones until 1983. The room dedicated to "1975-1976" showed three groups of important images. Leibovitz prepared a photo-report in the summer of 1975 of Arnold Schwarzengger in Pretoria, South Africa, documenting his preparation for defending his title of world champion and his announcing his retirement from bodybuilding. The next year, 1976, was election year, which she documented for Rolling Stone. For visitors interested in the history of photography and photographers, it was a special delight to appreciate her portraits of living photographers, a report where she both interviewed and photographed Helmut and June Newton, Guy Bourdin, Henri Cartier-Bresson, Richard Avedon, Andy Warhol, Ansel Adams and Jacques Henri Lartigue on assignment to Rolling Stone in 1976. The years "1977-1978" saw the inauguration of Jimmy Carter and the rise of punk music, illustrated most forcefully by the superb portrait of Patti Smith with metal barrels in flames behind her and other shots on stage. 1977 was also the year when Rolling Stone opened its office in New York. Leibovitz thus got to know Bea Feitler, who had been co-art director of Harper's Bazaar and Ms. in New York, and who redesigned Rolling Stone besides preparing their 10-year anniversary issue with a 50- 
page portfolio of Leibovitz's photographs in 1977: she would become a huge influence on Leibovitz in the coming years.

It is in the period "1979-1980" that a major aesthetic leap is noticeable in Leibovitz's career: she started using a medium format camera that produced square negatives and she definitely turned to colour for these photographs. This camera is particularly appropriate for pre-arranged, set-up portraits requiring careful lighting. This move accentuated and accelerated her development towards portrait and fashion photography, for which she has since become best known. She prepared a series for Life magazine of contemporary poets where she used a simple idea from their work to use as the theme in a visually appealing portrait. She prepared portraits in a similar manner of musicians, actors and other artists in colour. The iconic square photograph in colour showing John Lennon naked and curled up to Yoko Ono was taken a few hours before Lennon's assassination on 8 December 1980 and thus took on an unfortunate and unexpected significance and ultimately became a visual eulogy when it was published in Rolling Stone on 22 January 1981, with no caption on the title page.

The exhibition concludes in 1983 in the room "The 1980s", which was a turning point in her personal life and career. Bea Feitler had revamped Vanity Fair, published by Condé Nast and based in New York, and she invited her to take portraits for the prototype of the first issue: the new editor was convinced and she joined the staff there. She left Rolling Stone after thirteen years and moved back to the East Coast, to start working as a contributing photographer to Vanity Fair and later to Vogue. While this change meant leaving reportage as her method of working and a major medium of her artistic expression, this approach of incorporating narrative elements has never entirely disappeared from her portraits she would produce and she would become known for. The photographs of Hugh Hefner embracing a young woman before boarding his private jet with the Playboy logo on it or the portrait of Bianca Jagger with the propellers of a jet as the background are not simply brilliant images defining full glamour, but they convey the image of an oversized flamboyant lifestyle that was not (and still is not) available to most viewers of these images: incidentally, these images seem to be echoed regularly in the advertising campaigns for Michael Kors. Leibovitz has kept that rare ability to understand and capture a character and "to extend that understanding into the realm of the imagination", as Sante (2017) puts it.

\section{Concluding remarks}

There are a number of events and aspects of American life in the 1970s both Meyerowitz and Leibovitz photographed, but in characteristically different approaches. These included anti-war demonstrations in 1968, on either coast, but where Meyerowitz experimented with taking pictures from a child's perspective or taking instant shots of random people in the crowd and taking pleasure in the graphic quality of dogs barking at each other, Leibovitz was aiming at the orators such as Ginsberg and policemen with a smile on their face. References to car culture are abundant in both works. Both were aware that the car is a perfect framing device, it is the metaphor of the camera in a sense. Meyerowitz does not usually include parts of the car in his compositions when composing from within a moving car, and pushes colour to its extreme, for instance when composing around the colour of the car, or focuses on the graphic quality of the aspect of a carwash as an element of the urban environment. 
Leibovitz includes the car as her frame and context, and prepares her portraits of her subjects visibly driving a car, as in her "Driving series". One type of events both Meyerowitz and Leibovitz photographed was the launching of a spacecraft, Apollo-11 on 16 July 1969, "the Moon launch", for Meyerowitz, and three and a half years later Apollo-17 in the night of 7 December 1972 at Cape Kennedy, the last manned mission to the Moon, for Leibovitz. The way Meyerowitz treated this subject was as an event that represented a spectacle for the outsiders, a leisure activity for the masses, half a million of them, waiting for the launch in the dark of the night, perched on makeshift chairs placed on top of a car for a better visibility. For Leibovitz it was an assignment together with Tom Wolfe who reported on it for Rolling Stone and she took pictures of the launch itself and not of the crowd. Some points the two share are their transition simultaneously to colour photography and larger format cameras, in the-1970s, and the role photography played to help them overcome their timidity. While Meyerowitz was searching for ways to go beyond documenting reality and look for what these images mean in a wider context, Leibovitz was going for documenting and tracking reality in its utmost detail, from a personal rather than distant, "objective" perspective.

As a final remark, one can only hope that the coexistence of two events in Arles, the Rencontres d'Arles and the future programme offered by the LUMA Foundation, will make for better exhibitions for the public and the representation of the artists to enjoy, and for all the actors involved directly or indirectly in promoting photographic creativity and creating the market for this medium, joining their forces rather than fostering animosity and division.

\section{BIBLIOGRAPHY}

Arrivé, Mathilde. “Aaron Siskind, une autre réalité photographique”. In Miranda [Online], 12 | 2016, URL : http://miranda.revues.org/8383

Campany, David. Road Trips. Voyages photographiques à travers l'Amérique [original English title: The Open Road, Photography and the American Road Trip]. Paris: Editions Textuel, 2014.

Duponchelle, Valérie and Olivier Nuc. "Annie Leibovitz, les rock stars dans l'objectif à Arles". Le Figaro, updated 12 June 2017. URL: http://www.lefigaro.fr/arts-expositions/ 2017/05/30/03015-20170530ARTFIG00007-annie-leibovitz-les-rock-stars-dans-l-objectif.php

Hernandez, Brigitte. Edition spéciale “Rencontres d'Arles 2017”. Le Point. Free copy. 2017 (no page numbers).

Daniel Huber. "Walker Evans and Stephen Shore at the Rencontres de la Photographie d'Arles 2015". Miranda [Online], 12 | 2016a. URL : http://miranda.revues.org/8411

---. “Review of Images de star, Marilyn. La Dernière Séance, Bert Stern”. Miranda [Online], 12 | 2016b. URL: http://miranda.revues.org/8394 
Laurent, Jean-Marc. “Annie Leibovitz, légende vivante”. La République (édition du Centre), 11 June 2017. URL: http://www.larep.fr/arles/loisirs/art-litterature/2017/06/11/annie-leibovitzlegende-vivante_12439019.html

Annie Leibovitz, The Early Years, 1970-1983. Archive Project \#1. LUMA Foundation. Köln: Taschen, 2017. Leibovitz, Annie. La vie d'une photographe: 1990-2005 [A Photographer's Life: 1990-2005]. Paris: Editions de La Martinière, 2006.

Leibovitz, Barbara. Annie Leibovitz. Life Through a Lens. Educational Broadcasting Corporation, 2006; mk2 (French subtitled version) 2009.

Manac'h, Bastien. “Arles. Duo au soleil”. POLKA magazine, 2017, issue 38, p. 142-144.

Mercier, Clémentine. “Annie Leibovitz archivée vive à Arles”. Libération, 17 March 2017. URL: http://next.liberation.fr/images/2017/03/17/annie-leibovitz-archivee-vive-a-arles_1556212

Mora, Gilles. La Photographie américaine de 1958 à 1981. The Last Photographic Heroes. Paris: Editions du Seuil, 2007.

Petitbon, Sarah. “Joel Meyerowitz Early Works à la Salle Henri-Comte d'Arles”. POLKA magazine, 2017a, issue 38, p. 149.

---. “Trésors à vendre [Treasures for sale]”. POLKA magazine, 2017b, issue 38, pp. 30-34.

Sante, Luc. Essay in Annie Leibovitz, The Early Years, 1970-1983. Archive Project \#1. LUMA Foundation. Köln: Taschen, 2017.

Westerbeck, Colin. Joel Meyerowitz. Series 55. Paris: Phaidon. 2001.

Jean-Marc Laurent, available at http://www.larep.fr/arles/loisirs/art-litterature/2017/06/11/ annie-leibovitz-legende-vivante_12439019.html.

Catalogue reference

The Joel Meyerowitz exhibition did not have a catalogue.

Annie Leibovitz, The Early Years, 1970-1983. Archive Project \#1. 2017. Exhibition catalogue. LUMA Foundation. Taschen, Köln.

978-3-8365-6904-0

$28 €$, paperback, no page numbers, English edition (French exists too), with all the photographs.

\section{NOTES}

1. https://www.rencontres-arles.com/

2. The exhibition came with a catalogue, with essays by Anne Biroleau and Gilles Mora and an interview between Sylvie Aubenas and Jean-Claude Lemagny: Biroleau, Anne (ed.) Le choc de la photographie américaine. Paris, Bibliothèque nationale de France, 2008.

3. For a review of this Siskind exhibition, see Arrivé (2016) at: https://miranda.revues.org/8383

4. See Huber (2016a) for a review at: https://miranda.revues.org/8411

5. See Huber (2016b) on Bert Stern's The Last Session: https://miranda.revues.org/8394

6. The exhibition had something of a precursor in late 2016 in "Taking My Time" at Polka Gallery in Paris: http://www.polkamagazine.com/taking-my-time-part-i-de-joel-meyerowitz/

7. The other solo exhibitions under the heading The Experience of Territory included Michael Wolf: La vie dans les villes, Marie Bovo: стАнсы/Stances, Dune Varela: Toujours le soleil, Kate Barry: The Habit of Being and Christophe Rihet: Road to Death, together with some group exhibitions. 
8. See Huber (2016a) for their review at: https://miranda.revues.org/8411

9. Meyerowitz was present at the Opening Night of the festival on 4 July 2017 at the Théatre Antique and on 5 July, at the Collège Mistral, invited to a conversation, organized by Le Point and moderated by Brigitte Hernandez, in company of Adélie Ipanema, his galerist in Paris and founder of Polka magazine and gallery.

10. The framing was prepared by Circad, Paris.

11. It was printed by Processus, Paris.

12. The exhibition was made possible courtesy of the artist as well as the Howard Greenberg Gallery in New York City (http://www.howardgreenberg.com/), and Polka Gallery in Paris (http://www.polkagalerie.com/). Furthermore, the Fondation Louis Roederer was sponsor of the exhibition, their first sponsorship for the Rencontres.

13. A slightly different version of her report is available online at: https:// www.polkamagazine.com/avec-early-works-joel-meyerowitz-est-de-retour-a-arles/

14. The image is included in the picture gallery accompanying the article http:// www.polkamagazine.com/taking-my-time-part-i-de-joel-meyerowitz/

15. This choreographic aspect of street photography is the link between his early work and his later work with Paul Taylor's New York City Ballet that resulted in The Nutcracker in 1992.

16. See the article http://www.polkamagazine.com/taking-my-time-part-ii-de-joel-meyerowitz/ 17. Annie Leibovitz came to Arles to personally present her work and she spoke on 6 July 2017 at the Théâtre Antique in Arles, on the invitation of Sam Stourdzé, director of the Rencontres d'Arles.

18. The material about this programme reported in the present review can be found in the LUMA Arles Journal $\mathrm{N}^{\circ} 5$ (Summer 2017), freely distributed at the venue, but also available at: http:// www.luma-arles.org/

19. The figure is mentioned in the article by Jean-Marc Laurent, available at http:// www.larep.fr/arles/loisirs/art-litterature/2017/06/11/annie-leibovitz-legende-

vivante_12439019.html. Matthieu Humery in his interview for Libération mentions "between 6,000 and 10,000": http://next.liberation.fr/images/2017/03/17/annie-leibovitz-archivee-vive-aarles_1556212

20. These specifics are evoked by Matthieu Humery in his interview with Clémentine Mercier for Libération: $\quad$ http://next.liberation.fr/images/2017/03/17/annie-leibovitz-archivee-vive-aarles_1556212

21. See Manac'h (2017) on a clear presentation of the issues and tensions at stake.

22. Incidentally, Elliot Erwitt had two parallel exhibitions in Budapest, Hungary, one at the Mai Manó House, “Elliott Erwitt in Hungary", June 15-September 10, 2017, (http://maimano.hu/en/ kiallitasok/elliott-erwitt-hungary/) on his work when in Hungary on assignment to Time magazine in 1964, and a retrospective at the Capa Centre, June 15-September 10, 2017, http:// capacenter.hu/en/kiallitasok/elliott-erwitt-retrospective/.

23. For a recent and well-informed volume on the Condé Nast archives, see Nathalie Herschdorfer (2012) Papier glacé. Un siècle de photographie de mode chez Condé Nast [Coming into Fashion. A Century of Photography at Condé Nast], published by Thames and Hudson.

24. An instructive selection of 20 images concentrating on figures of music history has been compiled and commented on by Valérie Duponchelle and Olivier Nuc (updated 12 June 2017) for Le Figaro: http://www.lefigaro.fr/arts-expositions/2017/05/30/03015-20170530ARTFIG00007annie-leibovitz-les-rock-stars-dans-l-objectif.php

25. The figure appears in the article http://www.lefigaro.fr/arts-expositions/ 2017/05/30/03015-20170530ARTFIG00007-annie-leibovitz-les-rock-stars-dans-l-objectif.php 
INDEX

Keywords: American photography of the 1960s and 1970s, Joel Meyerowitz, street photography, Annie Leibovitz, pop culture, Les Rencontres de photographie d'Arles, LUMA Foundation

Mots-clés: photographie américaine des années 1960 et 1970, Joel Meyerowitz, photographie de rue, Annie Leibovitz, pop culture, Les Rencontres de photographie d'Arles, LUMA Foundation

Subjects: Photography

\section{AUTHORS}

\section{DANIEL HUBER}

Maître de conférences

Université de Toulouse

daniel.huber@univ-tlse2.fr 